\title{
G20 Ülkelerinde Sağlık Harcamalarının Ekonomik Büyüme Üzerindeki Etkisinin Analizi
}

\author{
Ali ÇELİK*
}

\begin{abstract}
$\ddot{O} Z$
Fiziki sermaye argümanina bilhassa 1980'li yllardan sonra bilgi, beceri ve maddi olmayan emek süreçlerinin dâhil olması yeni bir tarihsel momentuma işaret etmektedir. Fiziki sermayenin anti tezi olarak kavranan beşeri sermaye bu dönemsel koşulların ürünüdür. Beşeri sermayede, insan merkezli bir yaklaşım söz konusudur. Dolayısılla eğitim, sağlı, nüfus ya da bir bütün olarak demografik ögeler dikkate alınmaktadır. Fakat iktisat çalışmalarında beşeri sermaye dendiğinde ă̆ırlıkl olarak ĕgitim harcamalart ile ekonomik büyüme ilişsisine odaklanilmaktadır. Bu doğrultuda çalışmanın amacl, beşeri sermaye faktörünün bir diğer önemli bileşeni olan sağllk harcamalart ile ekonomik büyüme arasındaki iliskiyi panel veri ekonometrisi yöntemini kullanarak G20 ülkeleri özelinde araştırmaktır.

Bu bağlamda, Dumitrescu-Hurlin (2012) Panel Nedensellik testi sonucuna göre; ekonomik büyüme rakamlarından sağllk harcamalarına doğru tek yönlü nedensellik ilişkisi mevcuttur. Uzun dönemli eşbütünleşme katsayıları sonuçlarına bakıldığında ise panelin geneli için kişi başına düşen sağlık harcamalarındaki (SH) artışların, ekonomik büyüme (EB) rakamlarına pozitif ve istatistiki olarak anlaml düzeyde etkilediği bulgulanmıştır. Bu sonuca göre, kişi başına sağlık harcamalarındaki \%1'lik artıs, uzun dönemde ekonomik büyüme rakamlarını \%0.81 oraninda artırmaktadır.
\end{abstract}

Anahtar Kelimeler: Sağlık Harcamaları, Ekonomik Büyüme, Panel Veri Ekonometrisi JEL Sinıflandırması: I15, O47

\section{Analysis of The Effect of Health Expenditures on Economic Growth in G20 Countries}

\begin{abstract}
The inclusion of knowledge, skills and intangible labor processes in the physical capital argument especially after the 1980s indicates a new historical momentum. Human capital, which is understood as the anti-thesis of physical capital, is the product of these periodic conditions. In human capital, there is a people-centered approach. Therefore, education, health, population or demographics as a whole are taken into account. However, when human capital is mentioned in economic studies, it is mainly focused on the relationship between education expenditure and economic growth. The aim of the study is to investigate the relationship between health expenditure and economic growth, another important component of the human capital factor, in particular in G20 countries using the panel data econometrics method.

In this context, according to the Dumitrescu-Hurlin (2012) panel causality test, a one-way causality relationship exists from economic growth figures to health expenditure. Looking at the results of long-term co-ordination coefficients, it was found that increases in health expenditure (SH) per capita for the overall panel had a positive and statistically significant effect on economic growth (EB) figures. According to this result, it was concluded that $1 \%$ increase in health expenditure per capita boosted the long-term economic growth figures by $0.81 \%$.
\end{abstract}

*Dr. Öğr. Üyesi, İstanbul Gelişim Üniversitesi, Uygulamalı Bilimler Yüksekokulu, Uluslararası Ticaret Bölümü, alcelik@gelisim.edu.tr, ORCID Bilgisi: 0000-0003-3794-7786

(Makale Gönderim Tarihi: 23.09.2019 / Yayına Kabul Tarihi:04.03.2020) 
Key Words: Health Expenditure, Economic Growth, Panel Data Econometrics

JEL Classification: I15, O47

\section{GíRiş}

Ekonomik büyüme kavramı çeşitli biçimlerde tanımlanmaktadır. Kişi başına reel gelirdeki artış olarak kavranan ekonomik büyüme, aynı zamanda üretim öğelerinin (doğal kaynak, emek, sermaye, teknoloji gibi) miktarındaki artış ya da emek üretkenliğindeki ilerlemenin yansıması olarak milli gelir seviyesindeki pozitif yönlü gelişmeleri ifade etmektedir (Kirbitçioğlu, 1998). Kısaca, reel GSYİH'nin artış oranı, ekonomik büyüme oranını vermektedir (Fischer ve Dornbusch, 1998). Bu bağlamda esas itibariyle ülkelerin ekonomik büyümeleri iki temel biçimde gerçekleşir. İlki, tam istihdam koşulları altında mevcut üretim faktörlerinin daha etkin kullanımının sağlanması; ikincisi, tam istihdam koşulları altında hali hazırda kullanılan iktisadi kaynaklara yenilerinin ilave edilmesiyle ekonomik büyümenin sağlanmasıdır (Parlakyıldız, 2011: 44).

Özellikle Birinci Sanayi Devrim'inden sonra gündeme gelen, sermayelerin ya da ülkelerin rekabet gücünü, sermaye birikimini ve ekonomik büyüme performansını etkileyen veya hızlandıran en temel belirleyicilerden birinin teknoloji değişkeni olduğu ileri sürülmektedir. Teknoloji değişkeninin üretim sürecindeki konumu iktisat yazını içerisinde farklı biçimlerde kabul görmektedir. Bunlar arasında Klasik iktisatçılar ile Schumpeteryen okul, teknoloji değişkenini üretim sürecine içsel ve tüm sermayelerin (firmaların) eşit teknoloji düzeyine ulaşamayacağ 1 kabulünden hareket ederken, neoklasik okul ve takipçileri teknolojiyi üretim sürecine dişsal ve tüm sermayelerin (firmaların) homojen bir teknoloji seviyesine ulaşabileceğini savunmaktadırlar. Söz konusu iki farklı yaklaşım, firmaların karlılık analizlerini de etkileyen başat mekanizmalar olarak kabul edilmektedir.

Ekonomik büyüme göstergeleri için de merkezi önemi olan teknoloji olgusu, hemen hemen yarım yüzyıla yakın bir zaman diliminde birçok kuramcı tarafından modellenmiştir. Harrod, teknolojik gelişmeleri ekonomik büyüme çerçevesinde modelleyen ilk kuramcıdır. Bu ilk çaba, gerek Domar, Kaldor ve Robinson gibi Keynesyen ekolün gerekse de Solow ve Meade gibi neoklasik ekolün çeşitli katkılarıyla daha ileri taşınmıştır (Ducharme, 1998: 5). Fakat, Neoklasik modele göre, teknoloji değişkeni dişsal bir değişkendir. Uzun dönemde ekonomik büyümeye yol açacak tek değişkenin teknoloji değişkeninin olabileceği ileri sürülmektedir. Ayrıca uzun dönemde ülkeler arasındaki ekonomik gelişmişlik farklarının azalacağı hatta ortadan kalkacağı ve ülkelerin ekonomik olarak birbirini yakınsayacağı varsayılmıştır (Ertekin, 2005).

Ancak 1980 sonrası süreçte Ar-Ge ve yenilik tabanlı içsel büyüme yaklaşımları gündeme gelmiştir. Ar-Ge ve yeniliği önceleyen içsel büyüme modelleri ilk olarak P. Romer (1986) tarafindan geliştirmiş, Grossman ve Helpman (1989), Aghion ve Howitt (1992) gibi kuramcılar da bu yaklaşımın takipçisi olarak çeşitli düzeylerde katkılar yapmıştır. Aghion ve Howitt (1992) tarafından geliştirilen modelde; Ar-Ge faaliyetlerinin yenilikleri koşullayacağı, 
bunun da pozitif dışsallığa yol açarak, ekonomik büyüme dinamiklerini canlandıracağı ortaya konulmaktadır (Çetin ve Işık, 2014: 77). Özetle, teknolojik yenilik yapma amaciyla hareket eden Ar-Ge sektörü, beşeri sermaye ile bilimsel bilgi stokunu geliştirerek hem kendini hem de söz konusu değişkenlerin yeniden üretimini sağlamaktadır. $\mathrm{Bu}$ modellerin ayırt edici özelliği, teknoloji parametresinin üzerini sis perdesiyle örterek dişsal kabul eden yaklaşımlara karşı, teknolojik gelişmenin ve yeniliğin sistemin içsel bir mekanizması olarak kabul edilmesi ve ekonomik büyümenin kaldıracı olarak görülmesidir. İçsel büyüme modellerinde sermayenin her yeni yatırımı, yeniliklere ve bilgi stoklarındaki artışları teşvik edeceğinden gerek fiziksel gerekse de beşeri sermayede olumlu gelişmelere neden olacağını ve bunun da üretim sürecinde karşılaşılan azalan verimler problemine engel olacağı vurgulanmaktadır (Taban ve Şentürk, 2014). Öte yandan, içsel büyüme kuramcıları neoklasik büyüme kuramcılarının aksine teknolojinin, ülkeler arasındaki gelişmişlik farklarının yakınsayacağının yanı sıra gelişmişlik farklarını artıracağını ya da birbirinden uzaklaştıracağını ifade etmektedirler.

R.E. Lucas (1988), içsel büyüme modeline katkısı olan en önemli kuramcılardan biri olarak değerlendirilmektedir. "İktisadi Kalkınmanın Mekanizmaları Üzerine' 'adlı çalışmasında R. E. Lucas (1988), beşeri sermaye ile ekonomik büyüme arasındaki ilişkiyi ele alan ilk içsel büyüme modelini geliştirmiştir. Lucas, beşeri sermayeyi ekonomik büyümenin temel belirleyicisi olarak kabul eder. Neoklasik üretim fonksiyonu kullanarak fiziki sermaye ile teknolojik gelişmeye modelleyen Lucas, modellerine rasyonel beklentiler hipotezini de ekleyerek içsel büyüme modellerine yeni bir perspektif kazandırmıştır (Lucas, 1988). Lucas ayrıca, teknolojik gelişmelerin ve beşeri sermayenin ilerletilmesinde devlet desteklerinin önemine vurgu yapmaktadır.

Çalışmada, beşeri sermayenin bir diğer önemli bileşeni olan sağlık harcamaları ile ekonomik büyüme arasındaki ilişki incelenmektedir. Bu bağlamda, G20 ülkelerinde 2000-2016 yılları arası sağlık harcamalarının ekonomik büyüme üzerindeki etkisi yeni nesil panel veri analizi yöntemiyle araştırılmaktadır. Çalışmanın ilk bölümünde, Dünya Bankası veri setinden derlenmiş olan dünyadaki ve Türkiye'deki sağlı harcamaları ve ekonomik büyüme göstergeleri ile söz konusu değişkenlerin mahiyeti irdelenmekte; ikinci bölümde, sağlık harcamaları ile ekonomik büyüme ilişkisi inceleyen çalışmalara dair literatür özeti verilmekte; üçüncü bölümde, araştırma yöntemi ve ampirik bulgular sunulmaktadır. Çalışma, araştırmadan elde edilen sonuçlar ve genel bir değerlendirme ile tamamlanmaktadır.

\section{DÜNYADA VE TÜRKIYE'DE SAĞLIK HARCAMALARI İLE EKONOMIKK BÜYÜMENIN DINAMIKLLEİ}

Toplumsal hayatı sürdürülebilir kılmanın en önemli basamaklarından birinin sağlık koşullarını düzenlemek ve geliştirmek olduğu şüphe götürmez bir gerçekliktir. Sağlık harcamalarına tahsis edilecek paydaki artışla birlikte; sağlık sistemindeki iyileştirmelerin yanında hastane ve sağllk kurumlarının modernleştirilmesi, ileri teknoloji ile desteklenmiş sağlı cihazlarına ve 
teçhizatlarına erişiminin sağlanması, sağlığın kamusal hizmet olarak sunulması ve sağlıkta firsat eşitliğinin sağlanması sağlık koşullarının iyileştirilmesine katkıda bulunmaktadır. Ülkeden ülkeye farklılaşan sağlık harcamaları temelde sermaye birikimi dinamikleri ile toplumun geniş kesimlerinin sosyal taleplerine paralel olarak ilerlemektedir. İktisat yazınında özellikle büyüme teorisi içerisinde incelenen sağlık harcamaları, emek verimliliği ve ekonomik büyüme ile ilişkisi açısından birçok çalışmanın konusunu oluşturmaktadır. Bu bağlamda ilk olarak Grafik 1'de, sağlık harcamalarının dünyada ve çeşitli ülke gruplarındaki gelişimi ele alınmaktadır.

Grafik 1. Sağlık Harcamalarının GSYİH İçindeki Payı (\%)

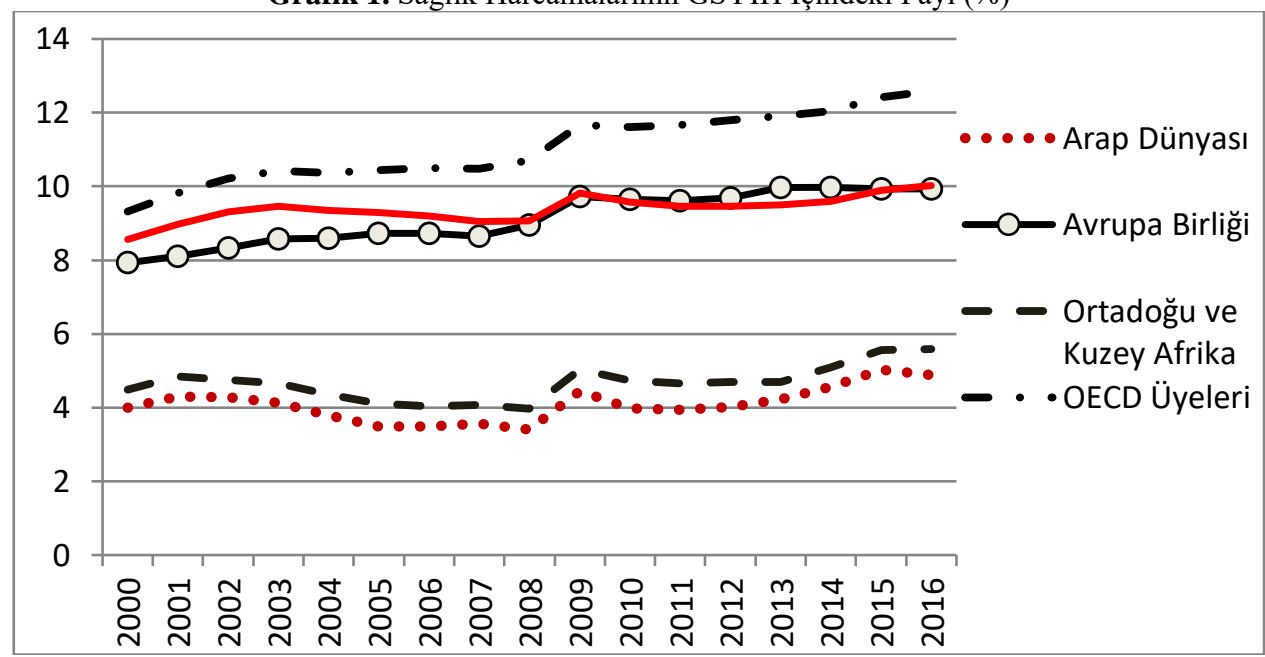

Kaynak: Dünya Bankası

Grafik 1'de görüldüğü üzere, OECD üyesi ülkelerin GSYİH'ları içindeki sağlık harcamaların payının dünya ortalamasının üzerinde olduğu gözlenmektedir. Dünya ekonomisi, OECD ülkeleri ve Avrupa Birliği açısından sağlık harcamalarının bu denli yüksek olmasının, verimlilik ya da ekonomik büyümeyi artırma amacı ikinci planda tutulduğunda; diğer taraftan, sağlık harcama kalemlerindeki ve tıbbi bakım hizmetlerinde ortaya çıkan maliyet artışlarının da etkisi söz konusudur. Diğer bir sonuç, sosyal devlet (refah devleti) anlayışının en önemli uygulayıcısı olarak bilinen Avrupa Birliği ülkelerinin sağlık harcamaları payının dünya ortalamasına yakın bir yerde seyretmesidir. Arap Dünyas1, Ortadoğu ve Kuzey Afrika'nın ise sağlık harcamalarının göreli payının dünya ortalamasının oldukça altında seyrettiği görülmektedir. Ülkelerin temel olarak gelişmişlik düzeyleri ile toplumsal kesimlerin sosyal kazanımları kuşkusuz bu resmi biçimlendiren etkenler arasında sayılabilir. Grafik 2'de 2000 yılı sonrası dünya ve çeşitli ülke grupları ekseninde satın alma gücü paritesi göz önüne alınarak belirlenen kişi başına genel hükümet sağlı harcaması sonuçları sunulmaktadir. 
Grafik 2. Satın Alma Gücü Paritesi Temelinde Kişi Başına Genel Hükümet Sağlık Harcaması (ABD Doları)

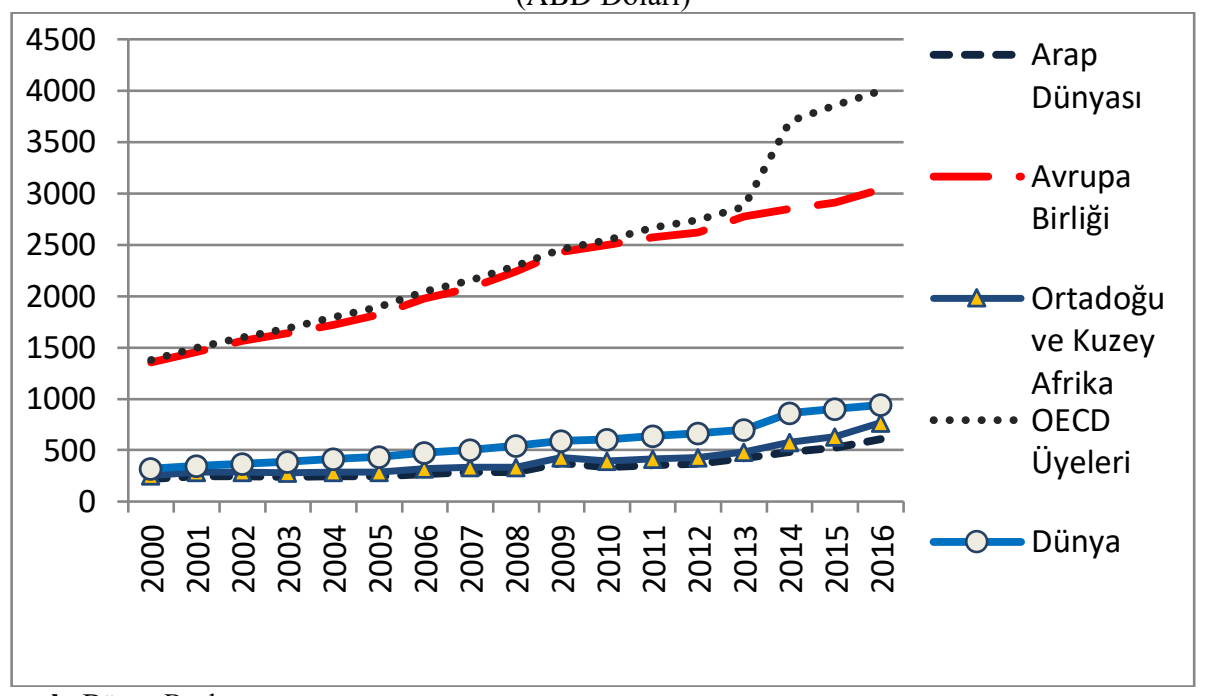

Kaynak: Dünya Bankası

Grafik 2'de görüldüğü üzere, OECD’ye üye ülkeler satın alma gücü paritesi temelinde oluşturulan kişi başı sağlık harcamaları noktasında da ele alınan ülke grupları arasında en üst sirada yer almaktadır. Bu ülke grubunun en yakın takipçisi Avrupa Birliği ülkeleridir. Avrupa Birliği’nde özellikle 2008 küresel krizinden sonra kişi başına sağlık harcamalarında göreli olarak aşağı yönlü bir eğilim göstermekte ve daha sonra tekrardan toparlanmaktadır. Arap Dünyası ile Ortadoğu ve Kuzey Afrika'nın satın alma gücü paritesi tabanlı kişi başına sağlık harcamaları rakamlarının dünya ortalamasının altında kaldığ 1 tespit edilmektedir. Grafik 1 ile Grafik 2 kıyaslandığında aralarında önemli bir farkın olmadığ 1 görülmektedir. Grafik 3'te dünya ve ülke gruplarının 1976 sonrası büyüme performansları sunulmaktadir.

Grafik 3. Ekonomik Büyüme Oranları (\%)

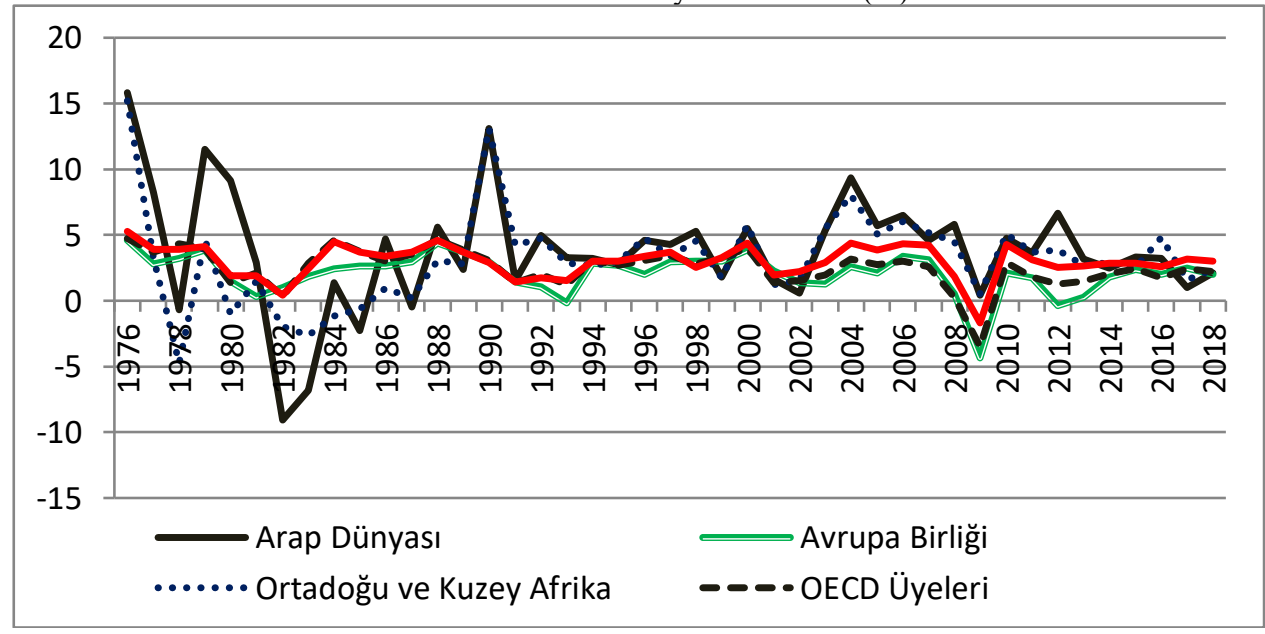

Kaynak: Dünya Bankası 
Grafik 3'te görüldügü üzere, dünya ekonomik sistemi 1970'li yıllardaki yapısal krizle birlikte derinden sarsılmıştır. Krizin etkisini hafifletmek veya tersine çevirmek amaciyla ortaya konan neoliberal politikalarla birlikte, kamu kesiminin payı küçültülüp özel girişimci birimlerinin payı genişletilmekte, sermaye hareketleri önündeki bariyerler kaldırılmakta, çalışma yaşamı esnekleştirilmekte ve bir bütün olarak uzun canlılık döneminde kazanılan hakların aşamalı olarak aşındırıldığı bilinmektedir. Yani, krizin etkisini ertelemek ya da telafi etmek amacıyla yeni karlılık alanlarının yaratılması adına her türlü girişimin normalleştirildiği kabul edilmektedir. Bununla birlikte toparlanma eğilimine giren dünya ekonomisi, 2008 yılında yeni bir krizle karşı karşıya gelmiştir. Söz konusu kriz neredeyse bütün ülkeleri etkisi altına almış, dünya ekonomisi bu dönemde \%3'e yakın bir seviyede küçülme göstermiştir. Bu gelişmeler genel olarak sosyal harcamaları özel olarak da sağlık harcamalardaki gelişmeleri önemli düzeyde etkilemektedir. Grafik 4'te 2016 y1lı için G20 ülkelerinde sağlik harcamalarının GSYİH içindeki payı sunulmaktadır.

Grafik 4. 2016 Y11 İçin G20 Ülkelerinde Sağlık Harcamalarının GSYİH İçindeki Payı (\%)

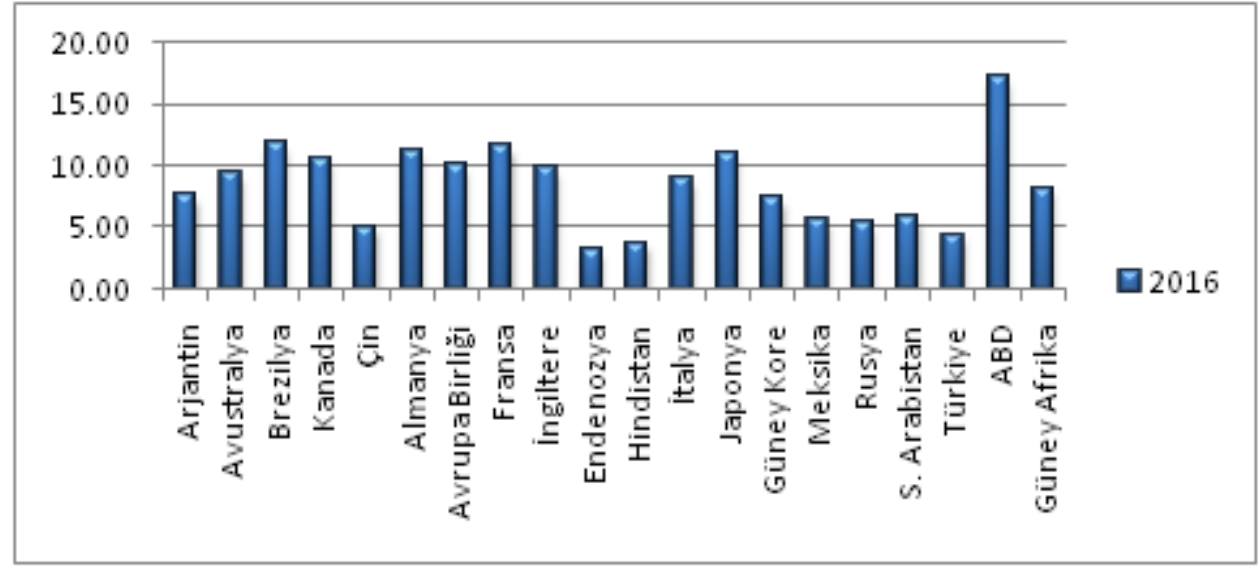

Kaynak: Dünya Bankası

Grafik 4'te görüldüğü üzere, 2016 yılı için G20 ülkeleri arasından sağlık harcamalarının GSYİH içindeki payının en yüksek olduğu ülke ABD olduğu tespit edilmiştir. ABD'yi Brezilya, İngiltere, Almanya ve Japonya takip etmektedir. Endonezya, Hindistan, Türkiye, Çin, Rusya ve Meksika'da sırasıyla G20 ülkeleri arasında sağlık harcamalarının en düşük olduğu ülkeler olarak gözlenmiştir. Geç kapitalistleşen ülkeler olmaları ve sosyal kazanımların yeterli düzeyde olmaması sağlık harcamalarındaki bu düşük payın en temel iki sebebi olarak ifade edilmektedir. Grafik 5'te, 2018 y1lı için G20 ülkelerinin ekonomik büyüme oranları sunulmaktadır. 
Grafik 5. 2018 Y1lı İçin G20 Ülkelerinin Ekonomik Büyüme Oranları (\%)

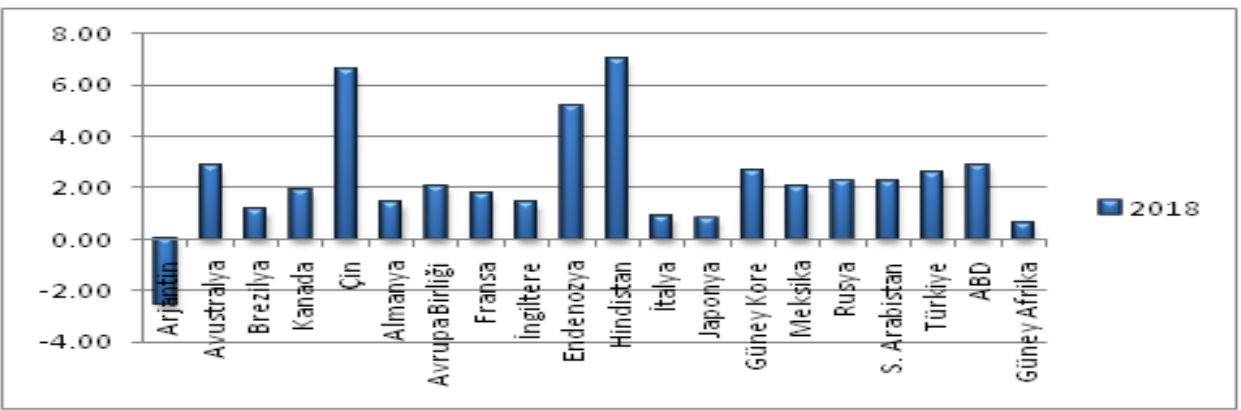

Kaynak: Dünya Bankası

Grafik 5'te görüldüğg̈ üzere, 2018 y1lı için ekonomik büyüme oranlarının en yüksek olduğu ülkenin sırasıyla Hindistan, Çin ve Endonezya'nın olduğu tespit edilmektedir. Bu ülkeler, yüksek büyüme rakamlarına sahip olmalarına rağmen sahip oldukları bu değerden sağlık harcamalarına ayırdıkları payın düşük olması oldukça dikkat çekicidir. Emek üretkenliklerini (verimliliğini) arttırıcı unsurların yanı sıra uluslararası işbölümündeki konumları gereği emek yoğun sektörler üzerinden dünya pazarına eklemlenen bu ülkeler, uluslararası alanda rekabetlerini emekçi sınıfların çalışma koşullarını düşürerek yapmaktadır. Bu yüzden, GSYİH içinde sağlı harcamalarına ayrılan paylar, bu ülkeler için maliyet unsuru olarak görülebileceğinden tercih sebebi olmamaktadır. Çünkü bu tercihin, ülkelerin rekabet gücünü zayıflatacağı kabul edilmektedir. Dolayısıyla, sağlık (sosyal) harcamalarının herhangi bir toplumsal itiraz gelmediği sürece düşük düzeyde tutulması sermaye sahiplerinin çıkarlarına hizmet etmekte ve rekabet güçlerini etkilemektedir. Diğer taraftan, 2018 y1lında G20 ülkeleri arasında ekonomik büyüme performansı kötü olan ülkelerin sirasıyla Arjantin, Güney Afrika, Japonya, İtalya, Brezilya oldukları görülmektedir. Bugünün güncel ekonomik ve siyasi gelişmelerine bakıldığında, dünya ekonomik sistemi 2008 küresel krizinin sert rüzgârını henüz savuşturabilmiş değildir.

\section{LITERATÜR TARAMASI}

İçsel büyüme modellerinin iktisat yazınında yer almasıyla beraber eğitim ve sağlık yatırımlarının (harcamalarının) bir almaşığı olan beşeri sermaye olgusunun ekonomik büyüme ile ilişkisini inceleyen oldukça fazla çalışma yapılmıştır. Ancak, söz konusu çalışmaların önemli bir çoğunluğu beşeri sermaye değişkeni olarak eğitim yatırımlarını ele almaktadır. Dolayısıyla beşeri sermaye ile ekonomik büyüme ilişkisini temel alan araştırmalar esas itibariyle eğitim yatırımları ile ekonomik büyüme ilişkisini incelemektedir. Söz konusu çalışmalarda, beşeri sermaye değişkeninin bir diğer önemli bileşeni olan sağlık harcamaları değişkeni genellikle ihmal edilmektedir. Bu bağlamda çalışmada, sağlık harcamaları ile ekonomik büyüme arasındaki ilişki araştırılmıştır. $\mathrm{Bu}$ çerçevede, sağlık harcamaları ile ekonomik büyüme arasındaki ilişkiyi ele alan çalışmalar aşağıda sunulmaktadır. 
Tablo 1. Sağlık Harcamaları ile Ekonomik Büyüme Arasındaki İlişkiyi İnceleyen Çeşitli Çalışmaların Özeti ${ }^{1}$

\begin{tabular}{|c|c|c|c|c|}
\hline Yazarlar & Kapsam & Dönem & Yöntem & Sonuç \\
\hline $\begin{array}{c}\text { Aurangzeb } \\
\text { (2003) }\end{array}$ & Pakistan & 1973-2001 & $\begin{array}{l}\text { Eşbütünleşme } \\
\text { ve Hata Terimi } \\
\text { Modeli }\end{array}$ & $\begin{array}{l}\text { Sağlık harcamaları ile ekonomik } \\
\text { büyüme aras ında kısa ve uzun } \\
\text { dönemde pozitif yönlü ve is tatistiksel } \\
\text { olarak anlamlı bir ilişki saptanmıştır. }\end{array}$ \\
\hline $\begin{array}{c}\text { Dreger ve } \\
\text { Remers } \\
(2005)\end{array}$ & $\begin{array}{c}21 \text { OECD } \\
\text { Ülkesi }\end{array}$ & $1975-2001$ & $\begin{array}{c}\text { Yeni Nesil } \\
\text { Panel } \\
\text { Ekonometrisi } \\
\end{array}$ & $\begin{array}{l}\text { Sağlık harcamaları ile ekonomik } \\
\text { büyüme arasında uzun dönem } \\
\text { iliş kis inin varlığı tespit edilmiştir. }\end{array}$ \\
\hline $\begin{array}{l}\text { Taban } \\
(2006)\end{array}$ & Türkiye & \begin{tabular}{|c|}
$1968-2003$ \\
\end{tabular} & $\begin{array}{c}\text { Nedensellik } \\
\text { Analizi }\end{array}$ & $\begin{array}{c}\text { Analizde kullanılan sağlık değiş kenini } \\
\text { ölçen parametreler ile ekonomik } \\
\text { büyüme aras ında çift yönlü } \\
\text { nedens ellik ilişkisi vardır. }\end{array}$ \\
\hline $\begin{array}{l}\text { Hartwig } \\
(2010)\end{array}$ & $\begin{array}{l}\text { OECD } \\
\text { Ülkeleri }\end{array}$ & 1970-2005 & $\begin{array}{c}\text { Panel Granger } \\
\text { Nedensellik }\end{array}$ & $\begin{array}{l}\text { Sağlık sermayes ine yapılan yatırımın } \\
\text { uzun dönem büyüme rakamlarına } \\
\text { pozitif yönlü bir etkisinin bulunduğu } \\
\text { tespit edilmiştir. }\end{array}$ \\
\hline $\begin{array}{l}\text { Çetin ve } \\
\text { Ecevit } \\
(2010) \\
\end{array}$ & $\begin{array}{c}15 \text { OECD } \\
\text { Ülkesi }\end{array}$ & 1990-2006 & $\begin{array}{c}\text { Panel } \\
\text { Ekonometri }\end{array}$ & $\begin{array}{l}\text { Sağlık harcamaları ile ekonomik } \\
\text { büyüme arasında herhangi bir iliş ki } \\
\text { tespit edilememiştir. }\end{array}$ \\
\hline $\begin{array}{l}\text { Bakare ve } \\
\text { Olubokun } \\
(2011)\end{array}$ & Nijerya & 1974-2008 & $\begin{array}{l}\text { En Küçük } \\
\text { Kareler } \\
\text { Yöntemi }\end{array}$ & $\begin{array}{l}\text { Sağlık harcamaları ile ekonomik } \\
\text { büyüme arasında pozitif yönlü bir ilişki } \\
\text { saptanmıştır. }\end{array}$ \\
\hline $\begin{array}{l}\text { Mehrara ve } \\
\text { Musai } \\
\text { (2011) }\end{array}$ & \begin{tabular}{|c|}
11 Petrol \\
İhracatçı \\
Ülke
\end{tabular} & 1979-2008 & $\begin{array}{c}\text { Gregory- } \\
\text { Hansen } \\
\text { Yapısal } \\
\text { Kırılmalı } \\
\text { Eşbütünleşme } \\
\end{array}$ & $\begin{array}{l}\text { Değiş kenler arasında uzun dönemli bir } \\
\text { ilişki yanında ekonomik büyümeden } \\
\text { sağlık harcamas ına doğru tek yönlü bir } \\
\text { nedensellik iliş kisi söz konusudur. }\end{array}$ \\
\hline $\begin{array}{c}\text { Tiraşoğlu } \\
\text { ve Yıldırım } \\
(2012)\end{array}$ & Türkiye & $\begin{array}{c}2006-2012 \\
\text { (Aylik) }\end{array}$ & $\begin{array}{c}\text { Yapısal } \\
\text { Kirılmalı } \\
\text { Zaman Serisi }\end{array}$ & $\begin{array}{l}\text { Sağlık harcamaları ile ekonomik } \\
\text { büyüme arasında uzun dönemli bir } \\
\text { ilişki mevcuttur. }\end{array}$ \\
\hline $\begin{array}{l}\text { Wang } \\
(2011)\end{array}$ & 31 Ülke & 1986-2007 & $\begin{array}{c}\text { Panel } \\
\text { Regresyon }\end{array}$ & $\begin{array}{l}\text { Sağlık harcamalarındaki artışının } \\
\text { ekonomik büyümeyi teş vik edeceğini, } \\
\text { fakat ekonomik büyümenin sağlık } \\
\text { harcamaları büyümes ini azaltacağı } \\
\text { sonucuna ulaşılmıştır. }\end{array}$ \\
\hline $\begin{array}{l}\text { Selim vd. } \\
\text { (2014) }\end{array}$ & $\begin{array}{c}27 \mathrm{AB} \\
\text { Ülkesi ve } \\
\text { Türkiye }\end{array}$ & 2001-2011 & $\begin{array}{c}\text { Panel } \\
\text { Eşbütünleşme } \\
\text { ve Hata } \\
\text { Düzelme } \\
\text { Modeli } \\
\end{array}$ & $\begin{array}{l}\text { Sağlık harcamaları ile ekonomik } \\
\text { büyüme arasında kısa ve uzun dönem } \\
\text { ilişkis inin varlığı saptanmıştır. }\end{array}$ \\
\hline $\begin{array}{l}\text { Şahbudak } \\
\text { ve Şahin } \\
\text { (2015) }\end{array}$ & $\begin{array}{c}\text { BRIC } \\
\text { Ülkeleri }\end{array}$ & \begin{tabular}{|c|}
$1995-2013$ \\
\end{tabular} & $\begin{array}{c}\text { Panel } \\
\text { Ekonometrisi }\end{array}$ & $\begin{array}{c}\text { Sağlık harcamalarının GSYİH içindeki } \\
\text { payı arttıkça, doğumdan yaşam } \\
\text { beklentisi ve ekonomik büyüme } \\
\text { oranları bu gidişattan pozitif yönde } \\
\text { etkilenmiş; ekonomik büyüme ile çocuk } \\
\text { ölüm oranları iliş kisi aras ında negatif } \\
\text { yönlü bir ilişkinin varlığı söz } \\
\text { konusudur. }\end{array}$ \\
\hline
\end{tabular}

\footnotetext{
${ }^{1}$ Literatür özetindeki diğer çalışmalar: Heshmati A.(2001); Devlin N. ve Hansen P. (2001); Hartwing J. (2008);
} Acemoğlu D. (2007); Odior E.S. (2011); Dreger, C. ve Reimers H. (2005); Ogundipe (2011) şeklindedir. 


\section{VERI SETI VE EKONOMETRIKK MODEL}

Çalışmanın analiz bölümünde, sağlık harcamaları ile ekonomik büyüme arasındaki ilişkinin boyutu ampirik olarak test edilmektedir. Bu ilişkinin varlığ , 2000-2016 dönemleri kapsamında yıllık veriler kullanılarak panel veri ekonometrisi yardımıyla incelenmektedir. Modelde satın alma gücü paritesi temelinde belirlenmiş döviz cinsinden kişi başına düşen sağlık harcamaları $(\mathrm{SH})$ ile döviz cinsinden (Amerikan Doları) ekonomik büyüme (EB) verileri doğal logaritması alınarak kullanılmaktadır. Ampirik analiz, Türkiye'nin de dahil olduğu G20 ülkerini kapsamaktadır ${ }^{2}$. Analizde kullanılan istatistikler ve makro ekonomik göstergeler, Dünya Bankası veri setinden derlenmiştir. Ayrıca seriler, Gauss 9.0 ile Eviews 8.0 programı kullanılarak analiz edilmiştir. Bu çerçevede çalışmada, sırasıyla kullanılan panel veri yönteminin teorik açılımları yapılmakta, ardından çalışmanın uygulama kısmı üzerine durulmaktadır. Analizde kullanılan değişkenler Tablo 2'de sunulmaktadır.

Tablo 2. Analizde Kullanılan Değişkenler

\begin{tabular}{|c|c|c|}
\hline Değişkenler & Değişkenin Açıklaması & Kaynak \\
\hline EB & $\begin{array}{c}\text { Ekomik Büyümenin Doğal } \\
\text { Logaritması }\end{array}$ & Dünya Bankası \\
\hline SH & $\begin{array}{c}\text { Sağlı Harcamasının Doğal } \\
\text { Logaritması }\end{array}$ & Dünya Bankası \\
\hline
\end{tabular}

Ekonometrik Model : $E B_{i t}=\alpha_{1 i}+\alpha_{2 i} S H_{i t}+u_{i t}$

$\alpha=$ Sabit Terim; $i=$ Yatay Kesit; $t=$ Zaman Boyutu; $u_{i t}=$ Hata Terimi olarak ifade edilmektedir.

\section{A.Yatay Kesit Bağımlıı̆ğı Testi}

Serilerin her birinin maruz kaldığı şokların diğer serileri etkileme düzeyinin tahminlenmesi yatay kesit bağımlılı̆̆ının testi yoluyla mümkündür. Dolayısıyla seriler arası yatay kesit bağımlılığının tahminlenmesi bulguların güvenirliğini ve yorumlanmasını önemli derecede etkilemektedir (Breush ve Pagan, 1980). Bu nedenle, birim kök, eşbütünleşme ve buna bağlı diğer testlerin analizi yapılmadan önce yatay kesit bağımlılık testi yapılmalıdır.

Zaman ve yatay kesit boyutlarının, YKB analizinde önemli bir yeri vardır. Çünkü YKB analizi yapılırken zaman ve yatay kesit boyutları kıstas alınır; analiz bu doğrultuda gerçekleştirilir. Zaman ve yatay kesit boyutlarına göre şekillenen analizler şu şekildedir. Berusch Pagan (1980) tarafindan geliştirilmiş CDLM1 testi, zaman boyutunun yatay kesit boyutundan büyük olduğu durumlarda; Pesaran (2004) tarafından geliştirilmiş CDLM2 testi, zaman boyutunun yatay kesit boyutuna yakın yahut küçük olduğu durumlarda; yine Pesaran (2004) tarafından geliştirilmiş CDLM testi, yatay kesit boyutunun zaman kesiti boyutundan büyük olduğu durumlarda kullanılmaktadır.

Bu testlere yönelik ilk çalışma Berusch Pagan(1980) tarafindan yapılmıştır. Buna göre, LM test istatistiğinin en ham biçimi aşağıda verilmektedir.

\footnotetext{
${ }^{2}$ Çalışmada analize konu olan ülkeler; Arjantin, Avustralya, Brezilya, Kanada, Çin, Almanya, Avrupa Birliği, Fransa, İngiltere, Endonezya, Hindistan, İtalya, Japonya, Güney Kore, Meksika, Rusya, Suudi Arabistan, Türkiye, ABD, Güney Afrika şeklindedir.
} 


$$
\text { CDLM1 }=T \sum_{i=1}^{N-1} \sum_{j=i+1}^{N} \hat{\rho}_{i j}^{2} \sim \frac{\chi_{N(N-1)}^{2}}{2}
$$

Ancak Berusch Pagan (1980)'ın sunduğu LM test istatistiği sapmalı sonuçlar üretmektedir. Pesaran, Ullah ve Yamagata (2008) ortaya çıkan söz konusu sapmay1, test istatistiğine varyans1 ve ortalamay1 ilave ederek çözümlemiştir. Bu formülasyonun (LM test ist.) ileriki safhadaki düzeltilmiş hali (3)'nolu denklemdeki gibidir (Pesaran vd., 2008);

$$
\begin{aligned}
L M_{a d j}= & \left(\frac{2}{N(N-1)}\right)^{1 / 2} \sum_{i=1}^{N-1} \sum_{j=i+1}^{N} \hat{\rho}_{i j}^{2} \frac{(T-K-1) \hat{\rho}_{i j}-\hat{\mu}_{T i j}}{v_{T i j}} \sim N(0,1) \\
& L M_{a d j} \rightarrow d N(0,1)
\end{aligned}
$$

Burada; $\hat{\mu}_{T i j}$ ortalamay1, $v_{T i j}$ varyansı temsil etmektedir. Bununla beraber, YKB testinin hipotezleri aşağıdaki gibidir:

$H_{0}$ : Yatay kesit bağımlilı̆ı yoktur.

\section{$H_{1}$ : Yatay kesit bağımlilı̆̆ vardır.}

Gerekli analizler gerçekleştirildikten sonra olasılık değeri $0,01,0,05$ ve 0,10 'dan küçük olduğunda, $\% 1, \% 5, \% 10$ anlamlılık düzeyi için $H_{0}$ hipotezi reddedilmektedir. Bu durumda, panelde kullanılan değişkenlerde YKB'nin varlığ 1 kabul edilmektedir (Pesaran vd., 2008). Nitekim çalışmada, Gauss kodları yardımıyla YKB'nin varlı̆ğ test edilmiş, elde edilen bulguların dökümü Tablo 3'de sunulmaktadır.

Tablo 3. Yatay Kesit Bağımlılı̆̆ Test Sonuçları

\begin{tabular}{|c|c|c|c|c|}
\hline Değişkenler & $\begin{array}{c}\text { Breusch-Pagan } \\
\text { LM1 }\end{array}$ & $\begin{array}{c}\text { Pesaran } \\
\text { Scaled LM2 }\end{array}$ & Pesaran CD & $\begin{array}{c}\text { Bias Adjusted CD } \\
\text { Test }\end{array}$ \\
\hline SH & 348.629 & 8.137 & -2.131 & 29.384 \\
& $(0.000)$ & $(0.000)$ & $(0.017)$ & $(0.000)$ \\
\hline EB & 389.100 & 10.124 & -1.313 & 20.141 \\
& $(0.000)$ & $(0.000)$ & $(0.095)$ & $(0.000)$ \\
\hline
\end{tabular}

Not: Tabloda olasılık değerleri parantez içinde gösterilmiştir.

Tablo 3'de yatay kesit bağımlılığı temelinde LM1, LM2, CD, LMadj testleri kullanılmıştır. $\mathrm{Bu}$ sonuca göre, sağlık harcamaları $(\mathrm{SH})$ ve ekonomik büyüme (EB) değişkenlerine ilişkin tespit edilen olasılık değerleri 0,05 'ten küçük olduğu için, $\mathrm{H}_{0}$ hipotezleri \%1 anlamlılık düzeyinde reddedilerek serilerde ve eş bütünleşme denkleminde YKB'nin varlığına karar verilmiştir. Yani bu sonuç, analiz edilen ülkeler arasında meydana gelen herhangi bir şokun diğer ülke ekonomilerini de etkilediğini ifade etmektedir. Dolayısıyla söz konusu ülkelerin politika yapıcıları diğer ülkelerde meydana gelen sosyo-ekonomik gelişmeleri ya da şokları dikkate almak durumundadır. Böylece, analizin devamında kullanılan panel testleri koşut olarak YKB testleri sonuçlarını göz önüne almalıdır. YKB testi sonuçlarına göre; analizin ileri safhasında yeni (ikinci) nesil panel testleri kullanılmalıdır. Bu bağlamda, ilk olarak seriler için yeni nesil panel birim kök testi sinanması gerçekleştirilecektir. 


\section{B. Panel Birim Kök Testi}

Bir önceki alt bölümdeki YKB bulgularının tespitinin ardından serilerin durağanlık analizinin daha etkin ve güvenilir vargılara ulaşmak için YKB'yi kıstas olarak göz önünde bulunduran birim kök testlerinden istifade edilmesi gerekmektedir. YKB'ye uygun olarak kullanılan testler, yeni nesil (ikinci nesil) birim kök testleri olarak tanımlanmaktadır. Panelde kullanılan serilerin durağanlık sınanması, Pesaran (2007) tarafindan geliştirilen ikinci nesil birim kök testlerinden olan CADF test yöntemi ile araştırılmıştır.

CADF testi sonuçlarına geçmeden önce panelde kullanılan bütün yatay kesit birimlerine (ülkeler) ait CADF testi istatistiği değerleri hesaplanmakta, akabinde söz konusu testlerin aritmetik ortalaması alınarak panel geneli için CIPS testi değerleri hesaplanmaktadır. Dolayısıyla CADF istatistiği ülke birimlerini analize tabi kılar ve durağanlık sonuçları verirken, CIPS istatistiği panel geneline dair durağanlık sonuçları üretmektedir. Çalışmada panelin geneli ve paneli oluşturan yatay kesit birimleri CADF birim kök testiyle incelenmiş, sonuçlar Tablo 4'te sunulmaktadır.

Tablo 4. CADF Panel Birim Kök Testi Sonuçları

\begin{tabular}{|c|c|c|c|c|}
\hline \multicolumn{5}{|c|}{ Test İstatistiğ $i$} \\
\hline Ülkeler & SH & $\Delta S H$ & $E B$ & $\Delta E B$ \\
\hline Arjantin & -2.26 & -2.31 & -1.29 & $-3.50 * * *$ \\
\hline Avustralya & -1.40 & -2.59 & -2.68 & -3.25 \\
\hline Brezilya & -0.79 & $-5.47 *$ & -0.08 & -2.97 \\
\hline Kanada & -2.40 & -1.71 & -1.68 & -3.13 \\
\hline Çin & -0.87 & -1.59 & -1.46 & -1.05 \\
\hline Almanya & -2.79 & $-4.67 *$ & -2.80 & -2.44 \\
\hline Avrupa Birliği & -1.35 & $-4.41 * *$ & -1.56 & -3.05 \\
\hline Fransa & 1.62 & -3.09 & -1.91 & $-3.59 * * *$ \\
\hline Ingiltere & -2.94 & -3.28 & -1.26 & -2.18 \\
\hline Endonezya & -1.38 & -2.14 & -0.76 & -1.09 \\
\hline Hindistan & -1.10 & -3.19 & -1.82 & -0.72 \\
\hline Italya & -0.91 & -2.61 & -2.09 & $-3.67 * * *$ \\
\hline Japonya & $-3.93 * *$ & $-9.61 *$ & -2.11 & $-4.46 * *$ \\
\hline Güney Kore & -2.13 & -0.51 & $-7.39 *$ & -2.90 \\
\hline Meksika & -2.54 & -1.53 & -2.31 & $-4.13 * *$ \\
\hline Rusya & -0.07 & -4.12 & -2.40 & -1.54 \\
\hline S. Arabistan & -1.39 & -1.72 & -3.23 & $-3.62 * * *$ \\
\hline Türkiye & $-3.61 * * *$ & -0.80 & -0.64 & -1.89 \\
\hline$A B D$ & $-4.75 *$ & -2.02 & -0.79 & -1.67 \\
\hline Güney Afrika & $-7.68 *$ & -2.23 & $-4.44 * *$ & $-3.78 * * *$ \\
\hline Panel (CIPS) & -1.84 & $-2.97 *$ & -2.13 & $2.73 * * *$ \\
\hline
\end{tabular}

Not: Pesaran (2007) çalışmasında sabit ve trendli model çerçevesinde CADF testi için kritik değerler; \%1, \%5 ve $\% 10$ anlamlılık düzeyinde sırasıyla $-4.96,-4.00$ ve -3.55 , CIPS testi için; $-2.92,-2.73$ ve -2.63 'dır. $\Delta$, fark operatörü olup değişkenin farkının alındığını göstermektedir. *, ** ve *** sırasıyla $\% 1, \% 5$ ve $\% 10$ anlamlılık düzeyinde serilerin durağan olduğunu göstermektedir.

Tablo 4'teki panel birim kök testi sonuçlarına göre, panelin geneli için serilerin düzey seviyesinde durağan olmadıkları, ancak birinci fark seviyesinde durağanlaştı̆̆ 1 tespit edilmiştir. Panelin geneli için serilerin tamamı I(1) olduğundan panel eşbütünleşme analizine geçilmesi mümkündür. Çünkü gerek zaman serisi analizinde olsun gerekse panel veri ekonometrisinde olsun eşbütünleşme analizine geçebilmenin varlık koşulu serilerin birinci fark I(1) seviyesinde durağan olmasıdır. 


\section{Eşbütünleşme Katsayılarının Homojenliğinin Sınanması (Slope Homogeneity Tests)}

Panel eş bütünleşme analizinde, eşbütünleşme katsayılarının homojenliği bu test yardımıyla analiz edilir. Böylece homojenlik testi sonuçları, Tablo 5'te sunulmaktadir.

Tablo 5. Pesaran ve Yamagata (2008) Homojenite Testi Sonuçları

\begin{tabular}{|l|l|l|l|}
\hline & & Test İstatistiği & Olasilık Değeri \\
\hline & $\widetilde{\Delta}$ & -2.172 & 0.985 \\
\cline { 2 - 4 } & $\widetilde{\Delta}_{a d j}$ & -2.379 & 0.991 \\
\hline
\end{tabular}

Tablo 5'te elde edilen bulgulara göre, çalışmada kullanılan modeller için hesaplanan homojenite testinin olasılık değerlerinin 0,05 'ten büyük olmasından ötürü $\mathrm{H}_{0}$ hipotezinin kabulüne karar verilmiştir. Buna sonuca göre, eş bütünleşme denklemine ait sabit ve eğim katsayısı homojendir. Bu sonuç, aynı zamanda analizin ileri safhasında verilen modeller için panel istatistiklerinin temel alınmasını gerekli kılmış ve eş bütünleşme yorumlarının geçerliliğini ve güvenilirliğinin panelin geneli için yapıldığı takdirde tutarlı olabileceğini ispatlamaktadır (Pesaran and Yamagata, 2008).

\section{Durbin-Hausmann Panel Eşbütünleşme Testi}

Düzey değerlerinde durağanlığa sahip olmayan, fakat farkları alındığı durumda durağan hale gelen seriler, bu fark alma işlemiyle beraber veri kaybı, geçmişte dönemde etkisi altında kaldığ şokları yok ettiği ve serilerin olması muhtemel uzun dönemli ilişkisini yok edeceği ileri sürülmektedir. $\mathrm{Bu}$ sebeple, farkları alınarak durağan hale getirilen veriler yardımıyla oluşturulan bir model, seriler arasında olması beklenen uzun dönemli ilişkileri tam manasıyla ortaya koyamayabilir. $\mathrm{Bu}$ koşullar altında tahminlenen seriler durağan olmasa dahi söz konusu değişkenlerin durağan bir kombinasyonu söz konusu olabilir. Bu durağan kombinasyon ise ancak eş-bütünleşme analizi yardımıyla tespit edilebilir (Tarı, 2010: 415).

Yatay kesit analizi, panel veri ekonometrisi ve kullanılacak test yöntemleri açısından hayati bir öneme sahiptir. Panel eşbütünleşme test yöntemi için de YKB aynı derecede önemli olduğu ileri sürülmektedir. YKB'nin sunduğu bilgiye paralel olarak, analiz sürecinde kullanılacak olan eş-bütünleşme testlerine karar verilmesi gerekmektedir. Panel eşbütünleşme analizi kullanılan çalışmaların önemli bir bölümü yatay kesit boyutundaki şokları dikkate almayan yani YKB'nin göz ardı edildiği çalışmalardır. Ancak yatay kesit bağımlılı̆̆ını dikkate almayan testlerin güvenilirlik sorunuyla karşılaşstığ1 görülmektedir. Zira bu problemin üstesinden gelebilmek amacıyla yatay kesit bağımlılı̆̆ına izin veren yeni nesil eş-bütünleşme testleri geliştirilmiştir (Yalçınkaya ve Kaya, 2016). Bu testlerin bazıları şu şekildedir; Westerlund-ECM (2007); Westerlund ve Edgerton (2007) LM Bootstrap, Westerlund-Haussman (2008), Westerlund (2009) Multiple Break Testi olarak siralanabilir.

Eşbütünleşme analizinde seriler arasında YKB'yi dikkate alan Westerlund (2008) Durbin-H test yöntemi tercih edilmiştir. Bu testin ayırt edici özelliği; 
bağımlı değişkenin birinci fark seviyesinde durağanlaşması, bağımsız değişkenlerin ise hem düzey hem de birinci fark seviyesinde durağan olması koşulunda panel eş bütünleşme analizi yapılmasına izin vermektedir. Ayrıca ortak faktörleri dikkate almaktadır (Westerlund, 2008). Testin hipotezleri şu şekildedir:

$$
\begin{aligned}
& H_{0}: \emptyset_{i}=1 \quad \text { Eş bütünleşme ilişkisi yok. (i=1,2,...n) } \\
& \left.H_{1}: \emptyset_{i}<1 \quad \text { Eş bütünleşme ilişkisi var. ( } \mathrm{i}=1,2, \ldots . \mathrm{n}\right)
\end{aligned}
$$

Durbin-H eş-bütünleşme yönteminde, uzun dönemli ilişkinin varlığı panel ve genel olarak iki biçimde tahmin edilmektedir. Otoregresif değişkenlerin tüm kesitler için aynı kabul edilmesi panel için geçerli iken, otoregresif değişkenlerin yatay kesitler arasında farklılaştı̆̆ını grup testi vermektedir. Analizi yapılan serilerin değerlendirilmesi evresinde, bulgulanan test istatistiğinin normal dağılım tablosunun kritik değerlerleriyle kıyaslanarak raporlanmaktadır. Son tahlilde, bulgulanan test istatistiği 1,645 'ten büyük olduğunda (\%5 anlamlılık düzeyi), $H_{0}$ reddedilmekte ve eş bütünleşme ilişkisinin varlı̆g 1 kabul edilmektedir. Tablo 6'da, Westerlund (2008) Durbin-Hausman panel eşbütünleşme testi sonuçları sunulmaktadır.

Tablo 6. Durbin Hausmann Panel Eşbütünleşme Testi Sonuçları

\begin{tabular}{|c|c|c|c|c|c|}
\hline Modeller & $\begin{array}{c}\text { Panel ve Grup } \\
\text { İstatistiği }\end{array}$ & $\begin{array}{c}\text { İstatistik } \\
\text { Değeri }\end{array}$ & $\begin{array}{c}\text { Olasılık } \\
\text { Değeri }\end{array}$ & $\begin{array}{c}\text { Kritik } \\
\text { Değer } \\
\mathbf{( \% 5 )}\end{array}$ & Karar \\
\hline Model: $\mathrm{EB}=\mathrm{f}(\mathrm{SH})$ & $\begin{array}{c}\text { Durbin-H Grup } \\
\text { İstatistiği }\end{array}$ & 7.816 & 0.000 & 1.645 & $\begin{array}{c}\text { Eş-bütünleşme } \\
\text { ilişkisi vardır. }\end{array}$ \\
\cline { 2 - 6 } & $\begin{array}{c}\text { Durbin-H Panel } \\
\text { İstatistiği }\end{array}$ & 4.163 & 0.000 & 1.645 & $\begin{array}{c}\text { Es-bütünleşme } \\
\text { ilişkisi vardır. }\end{array}$ \\
\hline
\end{tabular}

Tablo 6'da sunulan Durbin-Hausman (2008) panel eşbütünleşme testi sonucuna göre, Durbin-Hausmann grup ve panel istatistikleri değerlerinin 1,645 'ten büyük olduğu tespit edilmiştir. Böylece analiz edilen seriler arasında uzun dönemli ilişkinin varlığı söz konusudur. Yani, serilerin panel eşbütünleşik olduğu saptanmıştır.

\section{E. Panel Nedensellik Analizi}

Değişkenler arasında nedensellik ilişkisini belirlemek için YKB'yi dikkate alan ikinci nesil testlerden olan Dumitrescu-Hurlin(2012) tarafından geliştirilen panel nedensellik testi kullanılmıştır. $\mathrm{Bu}$ test, $\mathrm{T}>\mathrm{N}$ veya $\mathrm{T}<\mathrm{N}$ koşulunda yararlı sonuçlar vermektedir. Yani, zaman ve kesit boyut büyüklüklerine karşı duyarsız ve etkin sonuçlar üretebilmektedir. Ayrıca paneli oluşturan ülkeler arasında yatay kesit bağımlılığını göz önünde bulundurabilmesi, dengesiz panel veri setlerinde de etkin sonuçlara ulaşılmasını kolaylaştırmaktadır. Değişkenler arasındaki nedensellik iliş̧isi şu şekilde formüle edilmiş̧ir (Dumitrescu ve Hurlin, 2012: 5).

$$
Y_{i, t}=\alpha_{i}+\sum_{k=1}^{k} \gamma_{\mathrm{I}}^{(k)} Y_{i, t-k}+\sum_{k=1}^{K} \beta_{\dot{\mathrm{I}}}^{(k)} x_{i, t-k}+\varepsilon_{i, t}
$$

“' $K$ ”'simgesi optimum gecikme uzunluğunu, " $\alpha_{i}$ ” bireysel etkileri ifade etmektedir. Bunun yanında otoregresif parametre $\gamma_{\dot{\mathrm{I}}}^{(k)}$ ve regresyon katsayıs1 eğimi $\beta_{\dot{\mathrm{I}}}^{(k)}$ 'nın gruplar arasında farklılaşabileceği kabul edilmiştir. Denklemin işlerlik kazanması için denklemdeki katsayıların homojen ve durağan halde 
bulunması gereklidir. Testin boş ve alternatif hipotezleri aşağıda sunulmuştur (Dumitrescu ve Hurlin, 2012: 6).

$$
\begin{aligned}
& H_{0}: \beta_{t}=0, \quad \forall t=1,2, \ldots . N \quad \text { için, bütün yatay kesitlerde } \mathrm{X}^{\prime} \text { ten } \mathrm{Y}^{\prime} \text { ye nedensellik ilişkisi } \\
& \text { yoktur. } \\
& H_{1}: \beta_{i}=0, \quad \nabla_{i}=1,2, \ldots N_{t} \\
& \beta_{i} \neq 0, \quad \nabla_{t}=N_{t}+1, \ldots, N \text { için, bazı yatay kesitlerde } \mathrm{X}^{\prime} \text { ten } \mathrm{Y}^{\prime} \text { ye nedensellik ilişkisi } \\
& \text { vardir. }
\end{aligned}
$$

Dumetriscu-Hurlin (2012), Monte-Carlo simülasyonunu kullanarak test istatistiklerini ve bu istatistiklere ait olasılık değerlerini hesaplamaktadır.

\begin{tabular}{|c|c|c|c|}
\hline Modeller & Değişkenler & $Z_{N}^{H N C}$ & Karar \\
\hline \multirow[b]{2}{*}{$E B_{i t}=\alpha_{1 i}+\alpha_{2 i} S H_{i t}+u_{i t}$} & $E B \rightarrow S H$ & $5.85(0.00)$ & \multirow{2}{*}{$\begin{array}{c}\text { Ekonomik } \\
\text { büyümeden sağllk } \\
\text { harcamalarna doğru } \\
\text { tek yönlü } \\
\text { nedensellik ilişsisi } \\
\text { vardir. }\end{array}$} \\
\hline & $S H \rightarrow E B$ & $0.98(0.32)$ & \\
\hline
\end{tabular}
Analizde, $\quad \mathrm{T}<\mathrm{N}$ olduğu için yarı asimptotik dağılıma uygun $Z_{N}^{H N C}$ test istatistiği kullanılacaktır. Dumetriscu-Hurlin (2012) panel nedensellik analizi ardından elde edilen bulgular Tablo 7'de sunulmaktadır.

Tablo 7. Dumitrescu-Hurlin (2012) Panel Nedensellik Testi Sonuçları

Tablo 7'de elde edilen bulgulara göre, G20 ülkelerinin ekonomik büyüme rakamlarından sağlık harcamalarına doğru tek yönlü nedensellik ilişkisi tespit edilmiştir. Ülkeler, verimlilik ve bu yolla ekonomik büyüme patikalarını daha yüksek seviyelere çıkartmak amacıyla sağlı harcamalarına ayırdıkları payı artırmaları, ekonomik büyüme için kaldıraç işlevi görebilmektedir. Dolayısıyla, emek verimliliğini arttırıcı bir niteliği bulunan sağlık harcamalarının ekonomik büyüme performansına ivme kazandırması, ülkeler veya sermayelerin karlı yatırım tercihleri arasında yer almasına olanak sağlamaktadır.

\section{F. Uzun Dönem Eşbütünleşme Katsayılarının Tahmin Edilmesi}

Pesaran (2006) tarafından geliştirilmiş, YKB'nin varlığı altında geçerliliği bulunan ve güvenilir sonuçlar üreten uzun dönem eş bütünleşme katsayılarının tahminlenmesi aşamasında faydalanılan testlerden biri olan CCE (Ortak İlişkili Etkiler) yöntemi tercih edilmiştir. Ayrıca bu yöntemde, $\mathrm{T}>\mathrm{N}$ koşulunda kullanılabilen CCEMG (Ortak İlişkili Etkiler Ortalama Grup) ve $\mathrm{T}<\mathrm{N}$ koşulunda kullanılabilen CCEP (Havuzlanmış Ortak İlişkili Etkiler) olarak belirlenmiş iki tahminci geliştirilmiştir. En küçük karaler yöntemine dayanan ve karışı serilerde kullanılabilen CCE tahmincilerinde, çok faktörlü hata modeli test edilmektedir. Bu model aşağıda gibi sunulmaktadır (Pesaran, 2006: 971).

$$
\begin{aligned}
& y_{i t}=\alpha_{i} d_{t}+\dot{\beta}_{l} x_{i t}+e_{i t} ; \quad\left(i=1 \ldots N_{,}=1 \ldots . ., m=1 \ldots . k\right) \\
& e_{i t}=\gamma_{i} f_{t}+\varepsilon_{i t}
\end{aligned}
$$

$\mathrm{Bu}$ denklemlerde, $d_{t} ; \mathrm{n} \times 1$ gözlenen ortak etkileri (sabit veya mevsimsel yapay değişkenleri kapsayan), $x_{i t}$; bağımsız değişkenin yatay kesit ortalamalarını, $y_{i t}$ yatay kesit bağımlığını, $f_{t}$ gözlenemeyen ortak etkileri, $\varepsilon_{i t} ; d_{t}$ ve $x_{i t}$ 'den bağımsızlık olarak dağıtılmış olan hata terimi olarak ifade 
edilmektedir. Tablo 8'de, paneli oluşturan yatay kesit birimleri (ülkeler) için CCE, panelin geneli için ise CCEP tahmincileri kullanılmakta ve sonuçlar aşağıdaki gibi sunulmaktadır.

Tablo 8. Uzun Dönem Eş-Bütünleşme Katsayıları Tahmin Sonuçları

\begin{tabular}{|c|c|c|}
\hline Ülkeler & Katsayı & $t$-istatistiğ $i$ \\
\hline Arjantin & 2.35 & $4.67 *$ \\
\hline Avustralya & -0.60 & -0.78 \\
\hline Brezilya & -0.35 & -0.87 \\
\hline Kanada & 0.49 & 1.42 \\
\hline Çin & 0.72 & $3.81 *$ \\
\hline Almanya & -0.99 & -1.19 \\
\hline Avrupa Birliği & 3.56 & $10.81 *$ \\
\hline Fransa & 0.81 & 0.76 \\
\hline Ingiltere & 1.69 & $5.53 *$ \\
\hline Endonezya & -0.65 & $-2.94 *$ \\
\hline Hindistan & -0.42 & -1.37 \\
\hline İtalya & 1.74 & $3.11 *$ \\
\hline Japonya & 0.85 & $2.06 * *$ \\
\hline Güney Kore & 0.02 & 0.07 \\
\hline Meksika & -0.29 & -1.34 \\
\hline Rusya & 0.76 & $2.01 * * *$ \\
\hline S. Arabistan & 0.22 & $1.87 * * *$ \\
\hline Türkiye & 0.38 & 1.04 \\
\hline$A B D$ & 0.51 & $3.47 *$ \\
\hline Güney Afrika & -0.65 & $-1.71 * * *$ \\
\hline Panel (CCEP) & 0.81 & $2.59 * *$ \\
\hline
\end{tabular}

Not: *,**,*** sırasıyla $\% 1, \% 5$ ve $\% 10$ anlamlllık düzeylerini ifade etmekte; t-İst. değerleri ise Newey-West standart hatası kullanılarak hesaplanmıştır.

Tablo 8'deki uzun dönem eşbütünleşme katsayıları sonuçlarına bakıldığında, panelin geneli için kişi başına yapılan sağlık harcamalarındaki (SH) artışların, ekonomik büyüme (EB) rakamlarına pozitif ve istatistiki olarak anlamlı düzeyde etkilediği bulgulanmaktadır. Sağlık harcamalarındaki \%1'lik artışın, uzun dönemde ekonomik büyüme rakamlarını $\% 0.81$ oranında artırdığ sonucuna ulaşılmıştır. Yani, iki değişken arasındaki ilişki doğrusal yöndedir. Ülkeler bazında değerlendirildiğinde, anlamlılık düzeyi en yüksek olan Avrupa Birliği için elde edilen sonuçlar dikkat çekicidir. Buna göre; Avrupa Birliği’nde sağlık harcamalarına ayrılan \%1'lik payın, ekonomik büyüme rakamlarını \%3.56'lık düzeyinde artırdığı tespit edilmektedir. Türkiye için de iki değişken arasında pozitif yönlü bir ilişki tespit edilmiştir. Ancak, elde edilen sonuç istatistiksel olarak anlamlı değildir ve yorumlanamaz. Öte yandan, Endonezya ve Güney Afrika için sağlık harcamaları ile ekonomik büyüme arasında istatistiksel olarak anlamlı ve negatif yönlü bir ilişki tespit edilmektedir. Böylece, sırasıyla sağlık 
harcamalarındaki \%1'lik artış, Endonezya ve Güney Afrika'nın ekonomik büyümesini -\%0.65 seviyesinde düşürmektedir.

\section{SONUC}

Ana akım iktisatta sermaye olgusu, salt fiziki ve teknik bir süreç şeklinde tanımlanmaktadır. $\mathrm{Bu}$ yaklaşıma göre; sermaye denildiğinde akıllara makineler, binalar, ve hammaddeler gelmelidir. Heterodoks iktisatta ise sermaye olgusu daha derinlikli bir çözümlemeye tabi tutulmaktadır. Burada sermaye bir teknik süreçten ziyade aynı zamanda beşeri, toplumsal ve tarihsel ilişkilerin bir bütünüdür. Ancak fiziki sermaye argümanına bilhassa 1980'li y1llardan sonra bilgi, beceri ve maddi olmayan emek süreçlerinin dahil olması yeni bir tarihsel momentuma işaret etmektedir. Fiziki sermayenin anti tezi olarak kavranan beşeri sermaye bu dönemsel koşulların ürünüdür. Beşeri sermayede, insan merkezli bir yaklaşım söz konusudur. Dolayısıyla eğitim, sağlık, nüfus veya bir bütün olarak demografik öğeler dikkate alınmaktadır. Fakat iktisat çalışmalarında beşeri sermaye denildiğinde ağırlıklı olarak eğitim harcamaları ile ekonomik büyüme ilişkisine odaklanılmaktadır. Bu doğrultuda çalışmanın amacı da beşeri sermaye faktörünün bir diğer önemli bileşeni olan sağlık harcamaları ile ekonomik büyüme arasındaki ilişkiyi araştırmaktır.

Bu bağlamda çalışmanın ampirik sonuçları şu şekildedir; ilk olarak, yatay kesit analizi yapıldıktan sonra ikinci nesil panel veri analizi yöntemleri kullanımının daha güvenilir sonuçlar verebileceğine karar verilmektedir. Baz alınan ikinci nesil panel birim kök testlerinden olan CADF testi sonucuna göre serilerin birinci dereceden durağan olduğuna ve dolayısıyla panel eşbütünleşme analizi yapılması uygun görülmektedir. Dumitrescu-Hurlin (2012) Panel Nedensellik testi sonucuna göre; ekonomik büyüme rakamlarından sağlik harcamalarına doğru tek yönlü nedensellik ilişkisi tespit edilmektedir. Ülkelerin ekonomik büyümesi, beşeri sermayenin en önemli öğelerinden biri olan sağlık harcamalarını daha yüksek seviyelere çıkartmanın alt yapısını oluşturmaktadır. Dolayısıyla, ülke ekonomileri açısından emek verimliliğini arttırıcı bir niteliği bulunan sağlık harcamalarının; rekabet gücü, karlılık ve ekonomik büyüme göstergeleri bakımından kritik rolü bulunmaktadır. Böylelikle ekonomik gelişmişlik düzeyi sağlık harcamalarına ayrılan payı önemli derecede etkilediği ileri sürülmektedir.

Uzun dönemli eşbütünleşme katsayıları sonuçlarına bakıldığında, panelin geneli için kişi başına düşen sağlık harcamalarındaki (SH) artışların, ekonomik büyüme (EB) rakamlarına pozitif ve istatistiki olarak anlamlı düzeyde etkilediği bulgulanmaktadır. Sağlık harcamalarındaki \%1'lik artışın, uzun dönemde ekonomik büyüme rakamlarını \%0.81 oranında artırdığı sonucuna ulaşılmıştır. Yani, iki değişken arasındaki ilişkinin yönü doğrusal niteliktedir. Ülkeler bazında değerlendirildiğinde, anlamlılık düzeyi en yüksek olan Avrupa Birliği için elde edilen sonuçlar dikkat çekicidir. Buna göre; Avrupa Birliği'nde sağlik harcamalarına ayrılan \%1'lik payın, ekonomik büyüme rakamlarını \%3.56'l1k düzeyinde artırdığı tespit edilmektedir. Türkiye için de iki değişken arasında 
pozitif yönlü bir ilişki saptanmaktadır. Ancak, elde edilen bu sonuç istatistiksel olarak anlamlı değildir ve yorumlanamaz.

Sonuç olarak, sağlık harcamalarındaki artışların ekonomik büyüme rakamlarını olumlu yönde etkilediği gözlenmektedir. Ülke ekonomileri açısından kuşkusuz en önemli göstergelerden biri olan ekonomik büyüme, emek verimliliğini arttırıcı faktörler sayesinde ileri seviyelere taşınabilmektedir. $\mathrm{Bu}$ bağlamda, uygun sosyo-ekonomik koşullar sağlandığında eğitim ve sağlık harcamalarına tahsis edilen paydaki pozitif gelişmelerin emek verimliliğini yükselteceği ve bu doğrultuda ekonomik büyümenin sağlanabileceği ortaya konulmaktadir.

\section{KAYNAKÇA}

Acemoglu D. and Johnson S., (2007). Disease and Development: The Effect of Life Expectancy on Economic Growth, Journal of Political Economy. University of Chicago Press, vol. 115(6), pages 925-985, December.

Aghion, P. \& Howitt, P. (1992). A Model of Growth Through Creative Destruction, Econometrica, 60(2), 323-351.

Aurangzeb, A. Z. (2003). Relationship Between Health Expenditure and GDP in an Augmented Solow Growth Model for Pakistan: An Application of Co-integration and Error-Correction Modeling. Lahore Journal of Economics, 8(2), 1-18.

Arrow, K. J. (1962). The Economic Implications of Learning by Doing, The Review of Economic Studies, 29(3), 155-173.

Bakare AS, Olubokun S (2011). Health Expenditure and Economic Growth in Nigeria: An Empirical Study. J. Emerg. Trend Econ. Manage. Sci. 2(2):83-87.

Çetin M. ve Ecevit E. (2010). Sağlık Harcamalarının Ekonomik Büyüme Üzerindeki Etkisi: OECD Ülkeleri Üzerine Bir Panel Regresyon Analizi, Doğuş Üniversitesi Dergisi, Cilt: 11, Sayı: 2, ss. 166-182.

Çetin, M., Işık H.. (2014). Türkiye ve Avrupa Birliği Ekonomilerinde Yenilikler Ve Ar-Ge'nin Teşviki: Karşılaştırmalı Bir Değerlendirme, Maliye Dergisi, Sayı: 166, ss. 75-94, OcakHaziran.

Devlin, N. \& Hansen, P. (2001). Health Care Spending and Economic Output: Granger Causality.. Applied Economics Letters. Vol 8(8). 561-64. 10.1080/13504850010017357.

Ducharme, M, L. (1998). Measuring Intangible Investment Main Theories and Concepts, OECD 1998 Organisation For Economic Co-Operation and Development.

Dumitrescu, E. and Hurlin, C. (2012). Testing for Granger Non-Causality in Heterogeneous Panels. Economic Modelling 29: 1450-1460.

Dreger, C. and Reimers H.E. (2005). Health Care Expenditures in OECD Countries: A Panel Unit Root And Cointegration Analysis, International Journal of Applied Econometrics and Quantitative Studies, 2(2), 5-20

Ertekin, S, M. (2005). Yenilik ve Ekonomik Büyüme İlişkisi, Mevzuat Dergisi, Y11: 8, Sayı: 92, Ağustos.

Fischer, S. ve Dornbusch, R. (1998). Makro İktisat, Akademi \& McGraw-Hill Yayınları, İstanbul.

Hartwig, J. (2008). What Drives Health Care Expenditure?--Baumol's Model of 'Unbalanced Growth' Revisited. Journal of Health Economics, Elsevier, vol. 27(3), pages 603-623, May.

Hartwig, J. (2010). Is Health Capital Formation Good for Long-Term Economic Growth? Panel Granger-Causality Evidence for OECD Countries. Journal of Macroeconomics, Elsevier, vol. 32(1), pages 314-325, March.

Heshmati, A. (2001). "On the Causality between GDP and Health Care Expenditure in Augmented Solow Growth Model," SSE/EFI Working Paper Series in Economics and Finance 423, Stockholm School of Economics.

Grossman, G. M. and Helpman E.. (1989). Product Development ant International Trade. The Journal of Political Economy, 97(6), 1261-1283. 
Kibritçioğlu, A. (1998). İktisadi Büyümenin Belirleyicileri ve Yeni Büyüme Modellerinde Beşeri Sermayenin Yeri, Ankara Üniversitesi Siyasal Bilgiler Fakültesi Dergisi, 53(1), 207-230.

Lucas, R. E., (1988), On The Mechanics of Economic Development, Journal of Monetary Economics, 22, 3-42.

Mehrara, M., Musai, M.(2011). Granger Causality Between Health and Economic Growth in Oil Exporting Countries. Interdiscip. J. Res. Bus. 1(8), 103-108 (2011)

Odior, E. S. (2011). Government Expenditure on Health, Economic Growth and Long Waves in A CGE Micro-Simulation Analysis: the case of Nigeria. European Journal of Economics Finance and Administrative Sciences. 2011, 3, 101-113.

Ogundipe, M.A. and Lawal, N.A.,(2011). Health Expenditure and Nigerian Economic Growth. European Journal of Economics, Finance and Administrative Sciences, Issue 30.

Parlakyıldız, M, F. (2011). Fikrî Mülkiyet Haklarının Ekonomik Büyümeye Etkileri: G8 Ülkeleri Üzerine Bir Uygulama, Yüksek Lisans Tezi, Çukurova Üniversitesi Sosyal Bilimler Enstitüsü İktisat Anabilim Dalı: Adana.

Pesaran, M. H., (2006). Estimation and Inference in Large Heterogeneous Panels with a Multifactor Error Structure, Econometrica, 74 (4): 967-1012.

Pesaran, M. H. (2007). A Simple Panel Unit Root Test in The Presence of Cross- Section Dependence, Journal of Applied Econometrics, 22 (2), pp. 265-312.

Pesaran, M. H., Ullah A. ve Yamagata T. (2008). "A Bias- Adjusted LM Test of Error CrossSectionIndependence", TheEconometricsJournal, 11(1), pp. 105-127.

Romer, P. M., (1986). Increasing Returns and Long-Run Growth, The Journal of Political Economy, 95 (5), 1002-1037.

Selim, S., Uysal, D , Eryiğit, P . (2014). Türkiye'de Sağlık Harcamalarının Ekonomik Büyüme Üzerindeki Etkisinin Ekonometrik Analizi. Niğde Üniversitesi İktisadi ve İdari Bilimler Fakültesi Dergisi, 7 (3), 13-24. http://dergipark.org.tr/niguiibfd/issue/19756/211492

Şahbudak, E, ve Şahin, D. (2015). Sağlık ve Ekonomik Büyüme Arasındaki İlişkinin Analizi: BRIC Ülkeleri Üzerine Bir Panel Regresyon Analizi. İşletme ve İktisat Çalışmaları Dergisi, 3 (4), 154-160. http://dergipark.org.tr/iicder/issue/31650/347042

Taban, S. (2006). Türkiye'de Sağlık ve Ekonomik Büyüme Arasındaki Nedensellik İlişkisi. Sosyo Ekonomi, Say1: 4, Cilt: 4, ss. 31-46.

Taban S. ve Şentürk M. (2014). Türkiye'de AR-GE ve Ekonomik Büyüme, AİBÜ Sosyal Bilimler Enstitüsü Dergisi, Cilt: 14, Y1l: 14, Say1: 1, ss. 355-376.

Tarı R. (2010), Ekonometri, Genişletilmiş 6. Baskı, Umuttepe Yayınları, Kocaeli.

Tıraşoğlu, M. ve Yıldırım, B. (2012). Yapısal Kırılma Durumunda Sağlık Harcamaları Ve Ekonomik Büyüme İlişkisi: Türkiye Üzerine Bir Uygulama. Ejovoc (Electronic Journal of Vocational Colleges), 2 (2), 111-117. DOI: 10.1501/OTAM_0000000515

Yalçınkaya Ö. ve Kaya V. (2016). Eğitimin Ekonomik Büyüme Üzerindeki Etkileri: Düşük, Orta ve Yüksek Gelirli Ülkeler Üzerinde Bir Uygulama (1991-2011). AİBÜ Sosyal Bilimler Enstitüsü Dergisi, Cilt: 16 Yı1: 16 Say1:3.

Wang, K.M.(2011). Health Care Expenditure and Economic Growth: Quantile Panel-type Analysis. Econ. Model 28, 1536-1549 (2011). doi: 10.1016/j.econmod.2011.02.008.

Westerlund, J. (2006). Testing for Panel Cointegration with Multiple Structural Breaks. Oxford Bulletin of Economics and Statistics, 68, pp. 101-132.

Westerlund, J. ve Edgerton, D. L. (2007). A Panel Bootstrap Cointegration Test. Economics Letters, 97(3): 185-190.

Westerlund, J. (2008). Panel Cointegration Tests of The Fisher Effect. Journal of Applied Econometrics, 23, 193-233.

\section{SUMMARY}

One of the most important steps in making social life sustainable is to regulate health conditions. The increase in health expenditures is the basis for improving health conditions. Health expenditures, which differ from country to country, are progressing in parallel with the dynamics of capital accumulation and 
social demands of large segments of society. In the field of economics, In the field of economics, health expenditures, especially examined in the theory of growth, have been the subject of many studies in the axis of their relationship with labor productivity and economic growth. In the mainstream literature, the concept of capital is quite ambiguous. Here, the concept of correct capital is defined by attributing a pure technical process and a physical quality. According to this approach, when we say capital, we should think of machines, buildings, and raw materials. In heterodox economics, the concept of capital has been subjected to a deeper analysis. Here capital is not a technical process but a social and historical relationship as well. However, the incorporation of knowledge, skills and immaterial labor processes into the physical capital argument, especially after the 1980 s, points to a new historical momentum. Human capital, conceived as the antithesis of physical capital, is the product of these periodic conditions. In human capital, there is a human-centered approach. Therefore, education, health, population and demographic elements as a whole are taken into consideration. However, when human capital is mentioned in economic studies, it is mainly focused on the relationship between education expenditures and economic growth. The aim of this study is to investigate the relationship between health expenditures and economic growth which is another important component of human capital factor. Robert E. Lucas's 1988 paper (On the Mechanics of Economic Development) is the first model of endegenous growth theory that explains the relationship between human capital and economic growth. In this model, human capital is the source of growth. Lucas modeled physical capital accumulation and technological advances with the function of Neoclassical production, and brought a different perspective to endegenous growth models. In addition, he modeled the hypothesis of rational expectations in his studies and focused on technological development in the economy, physical capital and human capital (Lucas, 1988). In addition to education expenditures, health expenditures indicator is one of the most important pillars of human capital. Therefore, health expenditures have a central place in terms of internal growth theories.

After endegenous growth models take place in economic literature, it is seen that studies aimed at explaining the relationship between economic growth concept and human capital contribute to the literature. The concept of human capital can be explained by the developments in the field of education and health. Most of the studies focusing on the relationship between human capital and economic growth draw attention to the relationship between education expenditures and economic growth. However, developments in health expenditures can also affect the economic growth parameter.

In this study we investigated the relationship between health expenditure and economic growt in the G20 countries the periods between 2000 and 2016. In this context, the empirical results of the study are as follows; After the first cross sectional analysis, it was decided that the use of second generation panel data analysis methods could give more reliable results. According to CADF result 
which is one of the second generation panel unit root tests which are based on, the series are first order stationary and therefore panel cointegration analysis is considered appropriate. According to Dumitrescu-Hurlin (2012) Panel Causality Test; There is a one-way causality relationship from the economic growth figures to health expenditures in G20 countries. Economic growth processes of countries serve as leverage to increase the level of health expenditures, which is one of the most important elements of human capital concept, to higher levels. Hence, health expenditures, which have a feature of increasing labor productivity, can be one of the most rational options among the investment preferences of countries and groups in terms of encouraging or conditioned economic growth.

When the results of long-term cointegration coefficients were examined, it was found that increases in per capita health expenditures $(\mathrm{SH})$ for the overall panel had a positive and statistically significant effect on economic growth (EB) figures. It was concluded that the $1 \%$ increase in health expenditures increased the economic growth figures by $0.81 \%$ in the long term. That is, the relationship between the two variables is linear. When evaluated on a country-by-country basis, the results for the European Union with the highest level of significance are striking. According to this; It was found that the $1 \%$ share in health expenditures in the European Union increased the economic growth figures by $3.56 \%$. Turkey has been determined for a positive relationship between the two variables. However, the result obtained is not statistically significant and cannot be interpreted. As a result, it was found that increases in health expenditures had a positive effect on economic growth figures. 